\title{
EFIKASI DIRI REMAJA PUTRI DENGAN FOBIA SPESIFIK
}

\author{
Mohammad Yusuf Arfian ${ }^{1}$, Sriningsih ${ }^{2}$ \\ ${ }^{12}$ Universitas Mercu Buana Yogyakarta \\ ${ }^{2}$ sriningsih@mercubuana-yogya.ac.id
}

\begin{abstract}
Abstrak
Penelitian ini bertujuan untuk mendapatkan gambaran yang lebih konkrit tentang efikasi diri remaja perempuan dengan fobia spesifik. Subjek penelitian ini adalah 3 orang remaja putri berusia 12-21 tahun dengan fobia spesifik. Hasil analisis menunjukkan bahwa gambaran efikasi remaja putri dengan fobia memiliki karakteristik yang bervariasi. Partisipan PAS dan NNA memiliki karakteristik efikasi diri hampir serupa yaitu memandang ketakutannya sebagai hal yang mengancam, tidak memiliki dorongan untuk berani menghadapi ketakutannya, tidak berdaya untuk mengontrol ketakutannya dan memerlukan bantuan orang lain, tidak memiliki dorongan untuk berani menghadapi ketakutannya, dan memilih membiarkan ketakutannya tetap ada. Partisipan PAS pernah memiliki pengalaman berhasil menghadapi ketakutannya namun tidak memengaruhi keberaniannya menghadapi ketakutannya. Keluarga khususnya ibu selalu membantu PAS untuk menghindari laba-laba, sehingga efikasi diri yang dimiliki PAS tidak mengalami perubahan. Efikasi diri dikembangkan oleh NNA, karena ia kurang memiliki pengalaman berhasil menghadapi ular. Selama ini NNA tidak banyak menceritakan ketakutannya kepada orang lain, karena khawatir respon orang lain. Partisipan MAD memiliki karakteristik efikasi diri yang berbeda. Partisipan MAD menanamkan usaha yang kuat saat menghadapi ketakutannya. MAD merasa lega setelah dapat menghadapi objek yang ditakutinya. MAD merasa telah mampu menghadapi ketakutan dengan cara menenangkan diri. MAD merasa selama ini lingkungan menuntutnya untuk berhadapan dengan ketakutan. Selain itu penilaian masyarakat juga memengaruhi MAD untuk memiliki efikasi diri.
\end{abstract}

Kata Kunci: Efikasi, Remaja Putri, Fobia Spesifik

\section{SELF-EFFICACY OF TEENAGE GIRL WITH SPECIFIC FOBIA}

\author{
Mohammad Yusuf Arfian ${ }^{1}$, Sriningsih ${ }^{2}$ \\ ${ }^{12}$ Universitas Mercu Buana Yogyakarta \\ ${ }^{2}$ sriningsih@mercubuana-yogya.ac.id
}

\begin{abstract}
This study aims to get a more concrete picture of the self-efficacy of adolescent girls with specific phobias. The subjects of this study were 3 young girls, aged 12-21 years old with specific phobias. The results of the analysis show that the image of the efficacy of young women with phobias has varied characteristics. Two participants, PAS and NNA have almost the same characteristics of self-efficacy namely looking at their fears as threatening things, not having the courage to dare to face it, being powerless to control it and needing the help of others, not having the courage to face it, and choosing to let it remain. PAS once had the experience of successfully dealing with her fear but did not affect her courage in facing it. Her families, especially mothers, always help her to avoid spiders, so PAS's self-efficacy has not changed. Self-efficacy was developed by NNA, because she lacked experience in successfully dealing with snakes. During this time, she did not share much of her fear with others, for fear of their responses. MAD has different characteristics of self-efficacy. She instilled a strong effort in the face of her fear. She feels relieved after being able to face the object she feared. MAD feels she has been able to face fear by calming herself. She also feels that all this time the environment required her to face fear. In addition, community assessment also influences her to have self-efficacy.
\end{abstract}

Keywords: efficacy, young women, specific phobias 


\section{PENDAHULUAN}

Fobia spesifik merupakan sebuah ketakutan berlebih yang dimiliki individu terhadap objek atau situasi tertentu. Halgin \& Whitbourne (2009) mengungkapkan bahwa fobia spesifik adalah ketakutan irasional dan menetap pada objek khusus, aktivitas, dan situasi yang menyebabkan respons kecemasan secaratiba-tiba, menyebabkan gangguan signifikan dalam performa, dan menghasilkan perilaku menghindar. Fobia spesifik adalah salah satu gangguan psikologis yang umum dialami sekitar 7 sampai $11 \%$ dari populasi umum (APA dalam Nevid dkk., 2005). Kessler (dalam Halgin \& Whitbourne, 2009) mengungkapkan bahwa fobia spesifik dialami rata-rata $13,2 \%$ dalam sampel komunitas.

Menurut Nevid, dkk (2003) untuk mencapai pada taraf gangguan psikologis, fobia tersebut harus secara signifikan memengaruhi gaya hidup atau berfungsinya orang, atau menyebabkan distres yang signifikan. Dalam lingkungan yang mengharuskan mereka berhadapan langsung dengan stimulus penyebab fobia, tingkat kecemasan mereka meningkat dengan semakin dekatnya stimulus atau berkurangnya kemungkinan untuk melarikan diri dari situasi menakutkan tersebut (Halgin \& Whitbourne, 2009).

Ketakutan berlebih yang dimiliki orang dengan fobia tidak sebanding dengan ancaman yang timbul dari objek yang ditakuti. Nevid dkk. (2005) memaparkan bahwa pikiran pikiran irasional mengintensifkan keterangsangan otonomik, mengganggu rencana, memerbesar aversivitas stimuli, mendorong tingkah laku menghindar, dan menurunkan harapan untuk efikasi diri (selfefficacy). Menurut Bandura (Alwisol, 2004), fobia yang dipelajari dari pengamatan lingkungan, menjadi eksis akibat efikasi diri yang rendah. Orang merasa tidak mampu menangani suatu masalah yang mengancam sehingga muncul perasaan takut yang kronis.

Bandura (1997) menyatakan bahwa efikasi diri berguna untuk melatih kontrol terhadap stressor, yang berperan penting dalam keterbangkitan kecemasan. Penelitian Bandura (Baron \& Byrne, 2004) mengenai efikasi diri pada orang dengan fobia menunjukkan bahwa dengan meningkatkan efikasi diri dapat membantu orang dengan fobia mengurangi rasa takut yang dimiliki dan mengubah cara pandang individu dengan fobia menjadi lebih realistis, sehingga mereka merasa nyaman dalam menghadapi objek ketakutannya.

Alwisol (2004) mengemukakan bahwa tingkah laku dapat berubah, dalam sistem Bandura kuncinya adalah perubahan efikasi diri. Efikasi diri dapat diperoleh, diubah, dan ditingkatkan atau diturunkan, melalui salah satu atau kombinasi empat sumber. Pertama, pengalaman menguasai suatu prestasi (performance accomplishment), jika individu dengan fobia dapat mengubah efikasi diri yang dimiliki, maka ia berhasil mengatasi ketakutan yang dihadapi hal itu akan tergantung bagaimana pengalamannya ketika berhadapan dengan situasi fobia. Kedua, pengalaman vikarius (vicarious experience), individu dengan fobia dapat meningkat efikasi dirinya ketika mengamati keberhasilan orang lain dalam mengatasi rasa takutnya. Sebaliknya efikasi akan menurun jika mengamati orang yang 
kemampuannya kira-kira sama dengan dirinya ternyata gagal menghadapi rasa takutnya. Selanjutnya persuasi sosial (social persuation), efikasi diri juga dapat diperoleh atau dilemahkan melalui persuasi sosial. Individu dengan fobia dapat bermula melalui belajar dari lingkungannya. Terakhir adalah pembangkitan emosi (emotional/ pshysiological states), emosi yang muncul pada individu ketika mengatasi rasa takut dapat berpengaruh dalam perubahan efikasi dirinya. Orang dengan fobia memiliki taraf sensitivitas yang tinggi terhadap ketakutannya, mereka takut terhadap emosiemosi mereka atau takut bahwa keterangsangan tubuh yang diasosiasikan dengan keadaan tersebut akan menjadi tidak terkendali dan mengakibatkan konsekuensi yang merugikan (Williams dkk., dalam Nevid., 2005).

Karakteristik individu dengan efikasi diri tinggi adalah ketika individu tersebut merasa yakin bahwa mereka mampu menangani secara efektif peristiwa dan situasi yang sedang mereka hadapi (Bandura, 1997). Efikasi diri berguna untuk melatih kontrol terhadap stressor, yang berperan penting dalam keterbangkitan kecemasan. Individu yang percaya bahwa mereka mampu mengadakan kontrol terhadap ancaman, maka mengalami keterbangkitan kecemasan yang rendah. Kemampuan untuk mengatasi kecemasan dan depresi, dapat ditingkatkan melalui perasaan yang kuat akan efikasi diri (Bandura, 1997). Orang dengan efikasi tinggi lebih memungkinkan mengarahkan segenap tenaga ketika mencoba suatu tugas baru. Mereka juga lebih memungkinkan gigih dan tidak mudah menyerah untuk mencoba lagi ketika menghadapi tantangan (Ormrod, 2009).

Sementara karakteristik individu dengan efikasi diri rendah ditandai dengan perasaan tidak berdaya, cepat sedih, apatis, cemas, menjauhkan diri dari tugas-tugas sulit, cepat menyerah saat menghadapi rintangan, aspirasi rendah dan komitmen yang lemah terhadap tujuan yang ingin dicapai, dalam situasi sulit cenderung akan memikirkan kekurangan mereka (Bandura, 1997). Fobia yang dipelajari dari pengamatan lingkungan, menjadi eksis akibat efikasi diri pada orang fobia rendah, karena orang merasa tidak mampu menangani suatu masalah yang mengancam sehingga muncul perasaan takut secara kronis. Penyebab reaksi takut berlebihan disebabkan karena orang percaya bahwa dirinya tidak dapat menangani situasi tertentu secara efektif, sehingga perlu dikembangkan efikasi diri agar terjadi perubahan tingkah laku (Bandura dalam Alwisol, 2004).

Barlow (Pervin \& John 2001) memaparkan, penelitian menunjukkan jika orang-orang yang percaya bahwa mereka tidak bisa mengelola ancaman peristiwa akan mengalami permasalahan besar. Mereka juga dapat mengembangkan kognisi lebih lanjut mengenai gangguan seperti kecemasan dengan apa yang mungkin terjadi. Dengan kata lain, orang cemas cenderung memusatkan perhatian pada bencana yang ada di depannya, dan tidak mampu mengatasi hal itu, dari pada berfokus pada apa yang mungkin dilakukan untuk mengatasi situasi.

Orang dengan fobia jika berhadapan dengan situasi pembangkit kecemasan akan 
memiliki pikiran bahwa mereka perlu untuk keluar dari situasi kecemasan tersebut atau akan mendapat hal yang buruk. Pikiran-pikiran semacam tersebut mengintensifikasi keterangsangan otomatik yang mengganggu rencana, memerbesar aversivitas stimulus, mendorong tingkah laku menghindar, dan menurunkan harapan untuk efikasi diri sehubungan dengan kemampuan seseorang untuk mengendalikan situasi (Nevid dkk., 2005). Apa bila individu percaya bahwa, ia tidak memiliki kemampuan untuk menanggulangi tantangan-tantangan penuh stres dalam hidup, maka ia akan merasa semakin cemas ketika berhadapan dengan tantangantantangan tersebut. Orang dengan efikasi diri rendah, akan kurang yakin pada kemampuannya untuk melaksanakan tugas-tugas dengan baik, cenderung untuk berfokus pada ketidakadekuatan yang dipersepsikannya (Bandura dalam Nevid dkk., 2005).

Menurut Bandura (1997), tinggi rendahnya efikasi diri seseorang dalam tiap tugas sangat bervariasi. Hal ini disebabkan oleh adanya beberapa faktor yang berpengaruh dalam memersepsikan kemampuan diri individu. Faktor yang memengaruhi antara adalah jenis kelamin. Menurut hasil penelitian Susanto dan Wirawan (2008) gender dapat memengaruhi pertumbuhan efikasi diri, perempuan pada umumnya lebih melibatkan emosi mereka dibandingkan dengan laki-laki.

Data APA (Nevid, dkk., 2005) menunjukkan bahwa perempuan memunyai kemungkinan dua kali lebih besar untuk mengembangkan fobia spesifik. Perbedaan gender ini sampai taraf tertentu mungkin merefleksikan faktor budaya yang mensosialisasikan perempuan untuk tergantung kepada laki-laki demi mendapat perlindungan terhadap objek-objek yang mengancam dalam lingkungan.

Atas dasar latar belakang permasalah tersebut, peneliti ingin mengetahui gambaran yang lebih mendalam tentang efikasi diri remaja khususnya dengan fobia spesifik. Oleh karenanya dirumuskan permasalahan penelitian sebagai berikut: "Bagaimana gambaran efikasi diri remaja puteri dengan fobia spesifik?"

\section{Tujuan dan Manfaat Penelitian}

Penelitian ini bertujuan untuk mendapatkan gambaran yang lebih konkrit tentang bagaimana efikasi diri remaja perempuan dengan fobia spesifik.

Manfaat penelitian iini yaitu berguna bagi pengembangan khasanah psikologi perkembangan, sosial dan klinis berkaitan dengan efikasi diri remaja perempuan dengan fobia spesifik. Penelitian ini juga diharapkan dapat dimanfaatkan menjadi sumber informasi dan pemahaman menganai efikasi diri remaja puteri dengan fobia spesifik, sehingga diharapkan dapat memilih perilaku yang efektif dalam menghadapi ketakutannya. Selain itu dapat menjadi bahan acuan bagi penelitian berikut.

\section{METODE}

Penelitian ini merupakan jenis penelitian kualitatif dengan pendekatan studi kasus. Penelitian dengan pendekatan kualitatif memiliki tujuan memberikan diskripsi dan menjelaskan mengenai permasalahan dari 
penelitian secara menyeluruh dan mendalam (Poerwandari, 2007). Menurut Alsa (2014) penelitian dengan studi kasus dilakukan untuk memeroleh pengertian mendalam mengenai situasi dan makna sesuatu atau subjek yang diteliti. Penelitian studi kasus lebih mementingkan proses daripada hasil, lebih mementingkan konteks daripada suatu variabel khusus, lebih ditujukan untuk menemukan sesuatu daripada kebutuhan konfirmasi.

Sebjek dalam penelitian ini berjumlah 3 orang dengan kreteria yaitu mengalami fobia spesifik, berjenis kelamin perempuan, berusia antara 12-21 tahun, tidak memiliki batasan komunikasi (bisu). Selain tiga orang responden utama, dalam penelitian ini juga dilibatkan tiga orang responden yang berperan sebagai informan (significant person), yaitu orang yang diminta memberikan informasi mengenai seputar kehidupan pribadi responden utama.

Pengumpulan data penelitian dilakukan mulai tanggal 12 Maret 2015 hingga 31 Maret 2015. Pengumpulan data dalam penelitian ini menggunakan wawancara dan observasi. Penelitian ini menggunakan metode wawancara semi tersetruktur atau bebas terpimpin. Observasi pada penelitian ini dilakukan bersamaan dengan dilakukannya wawancara, selain itu observasi juga dilakukan pada waktu tidak dilakukannya wawancara (observasi lapangan). Proses observasi lapangan dalam penelitian dilakukan dengan data yang didapat dari wawancara bahwa telah diketahui mengenai batasan toleransi subjek dalam menghadapi objek ketakutannya. Nantinya batas kemampuan subjek untuk menghadapi objek fobia dijadikan pedoman saat pengkondisian lingkungan dalam observeasi. Selanjutnya subjek diberi informasi bahwa dalam observasi peneliti akan mengkondisikan lingkungan sehingga menyerupai saat subjek berhadapan dengan objek namun tetap dalam kondisi sesuai dengan kesepakatan yang telah dibuat di awal.

\section{HASIL DAN PEMBAHASAN}

PAS berusia 20 tahun, MAD berusia 20 tahun, dan partisipan terakhir adalah NNA berusia 18 tahun. Partisipan PAS memiliki ketakutan berlebih pada laba-laba, ia merasa kaki dan perut laba-laba adalah bagian tubuh yang dapat membuatnya ketakutan. PAS memiliki pengalaman tidak menyenangkan dengan laba-laba yaitu laba-laba pernah merayap di bagian kakinya dan melihat perut laba-laba yang hancur dan mengeluarkan cairan yang dinilai menjijikkan. Partipan MAD memiliki ketakutan saat melihat jenazah atau pergi menghadiri acara pemakaman (takziah). MAD beranggapan bahwa ketika melihat jenazah terus maka jenazah tersebut akan bangkit. Responden terakhir yaitu NNA, memiliki ketakutan berlebih pada ular. NNA menilai ular sangat menakutkan dan bagian yang baginnya menakutkan adalah kulitnya, ia merasa jijik ketika melihat kulit ular.

$$
\text { Halgin dan Whitbourne }
$$
berpendapat bahwa fobia spesifik (specific phobia) adalah ketakutan irasional dan menetap pada objek yang khusus, aktivitas, atau situasi yang menyebabkan respon kecemasan yang tiba-tiba, menyebabkan gangguan yang signifikan dalam performa dan menghasilkan perilaku menghindar. Beberapa orang memiliki ketakutan atau respon tidak menyenangkan 
terhadap objek-objek, situasi, atau makhluk hidup. Akan tetapi, jika respon seseorang terhadap sesuatu diantara hal yang dialami tersebut terlalu jauh di luar proporsi bahaya yang mengancam oleh stimulus, orang tersebut memiliki fobia (Halgin \& Whitbourne, 2009). Pada gangguan fobia, ketakutan yang dialami jauh melebihi penilaian tentang bahaya yang ada (Nevid, 2003).

Fobia spesifik seringkali bermula pada masa kanak-kanak. Banyak anak yang mengembangkan ketakutan terhadap objek atau situasi spesifik, tetapi hal ini akan berlalu. Meskipun demikian, beberapa di antaranya terus berlanjut untuk mengembangkan fobia kronis yang signifikan secara klinis (Merckelbach dalam Nevid, dkk., 2005). Partisipan MAD dan NNA telah memiliki rasa takut yang berlebih sejak usia kanak-kanak. Hal berbeda ditemukan pada PAS, ketakutan yang berlebih terhadap laba-laba bermula sejak usianya kurang lebih 15 tahun, saat berada di bangku Sekolah Menengah Atas (SMA).

Ketiga partisipan dengan fobia spesifik memerlihatkan gambaran efikasi diri yang khas. Berdasar Pendapat Bandura (1997), karakteristik individu dengan efikasi diri ditandai adanya perasaan yakin bahwa mereka mampu menangani secara efektif peristiwa dan situasi dihadapi, tekun dalam menyelesaikan tugas-tugas, percaya pada kemampuan diri yang dimiliki, memandang kesulitan sebagai tantangan bukan ancaman, suka mencari situasi baru, menetapkan sendiri tujuan yang menantang dan meningkatkan komitmen kuat terhadap dirinya, menanamkan usaha kuat dengan apa yang dilakukan dan meningkatkan usaha saat menghadapi kegagalan, berfokus pada tugas dan memikirkan strategi menghadapi kesulitan, cepat memulihkan rasa mampunya setelah mengalami kegagalan, dan menghadapi stressor atau ancaman dengan keyakinan bahwa mereka mampu mengontrolnya.

Berikut gambaran karakteristik efikasi diri pada partisipan PAS, merasa bahwa dirinya tidak yakin mampu menghadapi ketakutannya. PAS merasa tidak sanggup ketika saat ini berhadapan dengan laba-laba. PAS merasa sebaiknya membiarkan ketakutan yang dimiliki. PAS memandang ketakutannya sebagai hal yang mengancam. PAS selalu menghindari berada di tempat yang membuatnya berhadapan dengan laba-laba. PAS merasa bahwa belum memiliki komitmen untuk menghadapi ketakutannya. PAS memilih menjauh dari pada memiliki keberanian untuk menghadapi ketakutunnya. PAS membiarkan kegagalannya ketika menghadapi ketakutan, tidak memiliki strategi untuk menghadapi ketakutannya. PAS memerlukan waktu lama untuk mengembalikan rasa mampu setelah berhadapan dengan ketakutannya. PAS khawatir jika terjadi hal yang sama saat menghadapi laba-laba.

Bandura (1997) mendefinisikan efikasi diri sebagai keyakinan seseorang terhadap kemampuannya untuk mengatur dan melaksanakan tindakan-tindakan guna mencapai tujuan yang ditetapkan, sekaligus usaha untuk menilai tingkat dan kekuatan seluruh kegiatan dalam konteksnya. Efikasi diri adalah persepsi diri sendiri mengenai seberapa baik diri dapat berfungsi dalam situasi tertentu (Alwisol, 2004). Efikasi diri berhubungan dengan keyakinan 
bahwa diri memiliki kemampuan melakukan tindakan yang diharapkan.

Efikasi diri partisipan PAS dengan gambaran demikian, diperoleh karena pengalaman keberhasilan yang pernah PAS alami tidak memengaruhi agar memiliki keberanian menghadapi laba-laba. Selain itu pengalaman orang lain tidak meningkatkan efikasi diri yang dimiliki PAS. PAS melihat orang dengan ketakutan dan mampu mengurangi rasa takutnya, ia merasa tidak memiliki keinginan atau terdorong agar memiliki pengalaman sama dengan orang lain. Keluarga khususnya ibu selalu membantu PAS agar dapat menghindari laba-laba, selama ini menganggap bahwa wajar dan membantu agar tidak ada objek di lingkungan rumah. Hal tersebut membuat efikasi diri yang dimiliki PAS mengalami penurunan. Ingatan PAS tentang rasa jijik pada kaki laba-laba membuat efikasi dirinya mengalami penurunan.

Gambaran karakteristik efikasi diri pada partisipan MAD sebagai berikut, merasa tidak memiliki keyakinan menghadapi ketakutannya dengan efektif. Saat berhadapan dengan jenazah MAD khawatir akan terbayang-bayang bila jenazah tersebut akan bangkit kembali. Namun MAD berusaha untuk menghadapi ketakutannya dengan memulai berani melihat objek yang ditakuti. MAD berusaha menyembunyikan ketakutan agar terlihat mampu menghadapi ketakutannya. MAD merasa bahwa membutuhkan orang lain saat menghadapi ketakutannya, agar dapat mengalihkan bayangbayang ketakutannya. Partisipan MAD menanamkan usaha yang kuat saat menghadapi ketakutannya. MAD merasa lega setelah dapat menghadapi objek yang ditakutinya. MAD merasa telah mampu menghadapi ketakutan dengan cara menenangkan diri.

Beberapa faktor efikasi diri pada partisipan MAD, ia memiliki pengalaman berhasil saat menghadapi ketakutannya, ia merasa mampu menghadapi ketakutannya dan membuat efikasi dirinya meningkat. Pengalaman orang lain membuat MAD meningkatkan efikasi diri. MAD menilai jika seseorang dapat menghadapinya maka dirinya juga harus bisa menghadapi. MAD merasa selama ini lingkungan menuntut untuk berhadapan dengan ketakutan, selain itu penilaian dari masyarakat juga memengaruhi MAD untuk meningkatkan efikasi diri. MAD merasa lega setelah berhasil menghadapi ketakutannya. Perasaan yang dialami MAD setelah berhasil menghadapi ketakutannya dapat meningkatkan efikasi diri.

Gambaran efikasi diri yang diperlukan MAD memungkinkannya mengarahkan segenap tenaga ketika mencoba suatu tugas baru. Dengan demikian ia menjadi lebih mungkin dan tidak mudah menyerah untuk mencoba lagi ketika menghadapi tantangan (Ormrod, 2009). Orang yang ekspektasi efikasinya tinggi, percaya bahwa dia dapat mengerjakan sesuatu sesuai dengan tuntutan situasi dan harapan, hasilnya realistik atau memerkirakan hasil sesuai dengan kemampuan diri orang itu yang akan bekerja dan bertahan mengerjakan tugas sampai selesai (Alwisol, 2004).

Gambaran efikasi diri pada partisipan terakhir yaitu NNA sebagai berikut. NNA memandang ketakutannya pada ular sebagai hal yang mengancam. NNA tidak yakin dapat 
menghadapi ketakutannya secara efektif, merasa terganggu akan bayang-bayang ular. NNA merasa tidak percaya diri menghadapi ular karena saat berhadapan dengan ular sering merasa membutuhkan orang lain. NNA selalu merasa tidak berdaya untuk mengontrol ketakutannya dan memerlukan bantuan orang lain. NNA tidak memiliki dorongan untuk memiliki keberanian menghadapi ketakutannya. NNA lebih memilih membiarkan ketakutannya tetap ada, tidak meningkatkan komitmennya saat berhadapan dengan ketakutannya. NNA tidak pernah memikirkan untuk memiliki pertimbangan berani menghadapi ketakutannya. NNA sulit untuk mengembalikan rasa mampu setelah menghadapi ketakutannya. NNA selalu terbayang perasaan jijik terhadap bentuk kulit ular.

Berikut ini merupakan faktor yang membentuk efikasi diri pada partisipan NNA. Sebenarnya ketika NNA mengetahui ada orang lain yang dapat menghadapi ketakutannya, ia ingin mengalami hal serupa. Namun NNA merasa tidak mudah menurunkan ketakutan yang dimilikinya, karena ketakutan yang dimilikinya lebih menakutkan dibanding ketakutan yang dimiliki orang lain. Selama ini NNA tidak banyak menceritakan ketakutannya kepada orang lain, karena khawatir respon orang lain.

Individu dengan fobia memiliki sistem kewaspadaan yang terlalu aktif dalam menghadapi bahaya (Halgin \& Whitbourne, 2009). Wahyuni (2013) berpendapat bahwa individu yang memiliki efikasi diri tinggi akan mampu mengatasi masalah yang timbul akibat stimulus-stimulus yang terbentuk dari lingkungan. Begitu sebaliknya, individu dengan efikasi diri yang rendah akan cenderung menghindari tugas tertentu agar mereka tetap merasa aman. Gambaran ini ditemukan pada partisipan NNA.

\section{KESIMPULAN}

Partisipan PAS dan NNA memiliki karakteristik efikasi diri hampir serupa yaitu memandang ketakutannya sebagai hal yang mengancam, tidak memiliki dorongan untuk berani menghadapi ketakutannya, tidak berdaya untuk mengontrol ketakutannya dan memerlukan bantuan orang lain, tidak memiliki dorongan untuk berani menghadapi ketakutannya, dan memilih membiarkan ketakutannya tetap ada. Partisipan PAS pernah memiliki pengalaman berhasil menghadapi ketakutannya namun tidak memengaruhi keberaniannya menghadapi ketakutannya. Keluarga khususnya ibu selalu membantu PAS untuk menghindari laba-laba, sehingga efikasi diri yang dimiliki PAS tidak mengalami perubahan. Efikasi diri dikembangkan oleh NNA, karena ia kurang memiliki pengalaman berhasil menghadapi ular. Selama ini NNA tidak banyak menceritakan ketakutannya kepada orang lain, karena khawatir respon yang didapat. Partisipan MAD memiliki karakteristik efikasi diri yang berbeda.

Partisipan MAD menanamkan usaha yang kuat saat menghadapi ketakutannya. MAD merasa lega setelah dapat menghadapi objek yang ditakutinya. MAD merasa telah mampu menghadapi ketakutan dengan cara menenangkan diri. MAD merasa selama ini lingkungan menuntutnya untuk berhadapan 
dengan ketakutan. Selain itu penilaian masyarakat juga memengaruhi MAD untuk memiliki efikasi diri.

Berdasarkan hasil penelitian, maka peneliti mengajukan beberapa saran, pertama kepada responden, diharapkan partisipan hendaknya menyadari bahwa ia memiliki kemampuan dalam membantu menghadapi ketakutannya secara efektif. Partisipan dapat meningkatkan efikasi diri dengan cara memiliki pengalam berhasil saat menghadapi objek fobia. Belajar dari pengalaman orang lain yang mampu menghadapi ketakutannya. Berusaha berada dilingkungan yang mendorong untuk memiliki kemampuan menghadapi ketakutan. Mengurangi peningkatan emosi seperti takut, cemas, atau stres yang berlebihan.

Kepada lingkungan, diharapkan membantu orang dengan fobia dalam menghadapi objek yang ditakuti. Hendaknya membekali diri dengan pengetahuan mengenai fobia, sehingga mengetahui fakta-fakta yang tepat mengenai fobia. Orang lain di lingkungan diharapkan dapat menerima keberadaaan orang dengan fobia, dan menghindari membuat lelucon bersumber ketakutan yang dimiliki orang dengan fobia.

Kepada peneliti selanjutnya, diharapkan dapat menggali lebih dalam permasalahanpermasalahan yang dihadapi oleh remaja dengan fobia spesifik. Penambahan waktu untuk penggalian data dan menyiapkan strategi pengambilan data yang efesien, latar belakang lingkungan, dan jenis kelamin perlu dilakukan. Observasi pada penelitian ini memiliki kelemahan yaitu perilaku yang ditunjukkan oleh subjek dikhawatirkan tidak sesuai dengan perilaku pada kondisi nyata. Sehingga penelitian selanjutnya lebih memperhatikan proses dalam melakukan observasi agar perilaku yang nampak sesuai dengan kondisi nyata.

\section{DAFTAR PUSTAKA}

Alsa, A. (2014). Pendekatan Kuantitatif \& Kualitatif serta Kombinasinya dalam Penelitian, Yogyakarta: Pustaka Pelajar.

Alwisol. 2004. Psikologi Kepribadian. Malang: UMM Press.

American Psychiatric Association. (2010). Diagnostic and statistical Manual of Mental Disorders: DSM-IV-TR. Washington DC: American Psychiatric Association.

Azwar, Z., \& Niagara, S.T. (2011). Model Terapi Seft (Spiritual Emotional Freedom Technique) Untuk Mengatasi Gangguan Fobia Spesifik. Naskah Publikasi Penelitian Pengembangan IPTEKS. Malang: Universitas Muhammadiyah.

Bandura, A. (1986). Social Foundation Of Unifying Theory of Behavioral Change. Englewood Cliffs, NJ: Prentice Hall

Bandura, A. (1997). Self-Efficacy: The Exercise of Control. New York: W.H. Freeman and Company.

Baron, R.A., \& Byrne, D. 2004. Psikologi Sosial Jilid 1 Edisi 10. Jakarta: Penerbit Erlangga.

Davison, G.C., \& Neale, K. (2006). Psikologi Abnormal. PT Raja Jakarta: Grafindo Persada.

Fattah, A. Hussein. (2014). Perilaku Pemimpin \& kinerja Pegawai, Budaya Organisasi, Efikasi Diri, dan Keputusan Kerja. Yogyakarta: Penerbit Elmatera.

Feist, J., \& Feist, G.J. (2002). Theories of Personality. Bouston: McGraw Hill.

Friedman, H.S., \& Schustack, M.W. (2008). Kepribadian Teori Klasik dan Riset 
Modern jilid 2. Jakarta: Penerbut Erlangga.

Hadi, S. (2004). Metodologi Research. Yogyakarta: Andi Offsset.

Halgin, R.P., \& Whitbourne, S.K. (2009). Psikologi Abnormal Perspektif Klinis pada Gangguan Psikologi Edisi 6 Buku 1. Jakarta: Salemba Humanika.

Herdiansyah, H. (2010). Metodologi Penelitian Kualitatif Untuk Ilmu-ilmu Sosial. Jakarta: Salemba Humanika.

Irwanto. (2002). Psikologi Umum Buku Panduan Mahasiswa. Jakarta: PT Prenhallindo

Moleong, L.J. (2011). Metodologi Penelitian Kualitatif. Bandung: Remaja Resdakarya.

Monks, F.J. Knoers., \& Haditono, S R. (2008). Psikologi Perkembangan Pengantar dalam Berbagai Bagian. Yogyakarta: Gajah Mada University Press.

Nasution, S. (2003). Metode Penelitian Naturalistik Kualitatif. Bandung: Tarsito.

Nevid, J.S. R, Spencer A., \& Greene, B. (2005). Psikologi Abnormal Jilid 1. Alih Bahasa Tim Fakultas Psikologi Universitas Indonesia. Jakarta: Erlangga.

Ormrod, J.E. (2009). Psikologi Pendidikan: Membantu Siswa Tumbuh dan Berkembang jilid 2. Jakarta: Penerbit Erlangga.

Pervin, L.A., \& John, O.P. (2001). Personality; Theory and Reasearch. 8 ed. New York: John Wiley \& Sons, Inc.

Poerwandari, K. (2007). Pendekatan Kualitatif Dalam Penelitian Psikologi. Jakarta: Fakultas Psikologi Universitas Indonesiaa.

Santrock, J.W. (2002). Life-Span Development. Perkembangan Masa Hidup. Jakarta: Erlangga.

Sugiyono. (2011). Statistik Untuk Penelitian. Bandung: CV Alfabeta.
Supratiknya, A. (1995). Komunikasi Antar Pribadi. Yogyakarta: Kanisius.

Susanto, I., \& Wirawan, H.E. (2008). Gambaran Self Efficacy Orang Tua Anak Autisme. Naskah Publikasi. Jakarta:

Universitas Tarumanagara. Wahyuni, Sri. (2013). Hubungan Efikasi Diri dan Regulasi Emosi dengan Motivasi Berprestasi pada Siswa SMK Negri 1 Samarinda. Naskah Publikasi Ejournal Psikologi FISIP UNMUL. Samarinda: Universitas Mulawarman.

Widiyanti, M.D., \& Marhenti, Adijanti. (2013). Perbedaan Efikasi Diri Berdasarkan Tipe Pola Asuh Orang Tua Pada Remaja Tengah di Denpasar. Jurnal Psikologi Udayana, 1(1).

Yin, Robert. (2013). Studi Kasus Desain \&Metode Edisi 1 Cetakan 12. Jakarta: PT. RajaGrafindo Persada (Raja Wali Perss). 